\title{
Influence of different exposition of larch wood facade models on their surface degradation processes
}

\author{
Irena Štěrbová, Eliška Oberhofnerová, Miloš Pánek*, Ondřej Dvořák, Miloš Pavelek \\ Czech University of Life Sciences Prague, Faculty of Forestry and Wood Sciences, Kamýcká 129, \\ CZ-16500 Praha 6-Suchdol, Czech Republic
}

\begin{abstract}
Wood, as a building material, is nowadays more often used outdoors. From the point of view of environment care, wood constructions and use of renewable materials belongs between modern increasing trends in industry. Wooden facades, more often used without surface treatment, are the important part of this trend. In Central Europe, European larch (Larix decidua) and Siberian larch (Larix sibirica) are especially popular materials for wooden facade elements. The aim of this study is to characterize the surface degradation of untreated facade models from both European and Siberian larch wood. The wood species, orientation to the sides of the world and construction type of the facade were the evaluation factors, which were regularly examined during 24 months of outdoor exposure via measuring the changes of surface colour, gloss, wettability and visual appearance in the form of cracks and resin leaking. The influence of all evaluated factors on the measured properties was determined. The results of this work can help to proper use of untreated larch wood on facade elements in practice.
\end{abstract}

Key words: colour changes; facades; larch wood; surface degradation; weathering

Editor: Bohdan Konôpka

\section{Introduction}

Wood, as a building material, is well known for many advantages. But there is a need to use it in a way to protect it against some specific factors, which negatively affect its service life, functionality and appearance. This process is called bio-degradation (Hrapková 2012). According to study of Gielen (1997), the production of all building materials is responsible for $8-12 \%$ of all $\mathrm{CO}_{2}$ emissions in Western Europe. The use of wood as a building material can reduce this number (Goverse et al. 2001; Bribiàn et al. 2011). Already in the last century the trend of ecological construction became familiar and the modern wood constructions are the proof that wood still belongs between popular and abundantly used building materials (Ingo 2011; Kržišnik 2018).

Untreated wood, as a material for facade, can be a cost-effective alternative to materials with an applied coating system, as it requires limited maintenance. On the other hand, more information about final costs, environmental impact of building components and servicelife are needed (Feist \& Hon 1984). In the study of Gupta et al. (2011), the FTIP analysis was used to estimate the prediction of service life of wooden facade elements. Based on their results, the key is to understand the degradation processes of untreated wood during weathering. Generally, the prediction of service life of wood components is the main factor of research, which requires careful examination of material's properties (Brischke et al. 2008; Gupta et al. 2011). Current trends even favor facade elements without surface treatment, even though the visual appearance of untreated wood changes over time due to weather conditions (Feist \& Hon 1984; Hirche 2014; Lesar et al. 2016).

Wooden facades are usually made from softwoods and used more and more often without surface treatment (Ingo 2011). According to Connell (2004), during last decade there was a trend of increasing application of domestic wood species. The reasons for that are the lower costs of transport, lower emission of $\mathrm{CO}_{2}$ and negative perception of tropical wood use, which is often connected with deforestation (Sohngen et al. 1999). In the area of Czech Republic, there are several domestic wood species, which are suitable for facade production - spruce, fir, larch and Douglas fir among softwoods and oak, Black locust or chestnut among hardwoods. But practically, hardwoods are not used at all for this purpose. The reason are more disadvantages of more durable hardwoods (for example Quercus sp. or Robinia pseudoacacia) - their 
higher density (Požgaj et al. 1993) and thus increased facade weight, higher price and also higher susceptibility of lumber to shape deformations and formation of larger cracks. Furthermore, various types of thermally modified wood are used, preferably made of Scots pine or Norway spruce (Reinprecht 2016). The most important factors for the selection of suitable wood species are the number and width of annual rings - the denser annual rings stands for higher durability of wood (Ingo 2011). Frequently used larch wood belongs to the durability class 3 according to EN 350 (2016). European larch (Larix decidua Mill.) is characterized with distinguished sapwood and heartwood, sapwood is narrow and yellowish, heartwood is from red-brown to red-purple colour and turns dark on the air (Wagenführ 2003; Gierlinger et al. 2003). European larch wood does not have a lot of resin canals but they can be recognized in all directions well known for wood structure - radial, tangential and longitudinal. This wood species is dimensionally stable a relatively resistant to acids, climatic changes and attack of insects and fungi (Musil 2007). Sapwood of Siberian larch (Larix sibirica) is yellow, heartwood is red-brown. Siberian larch wood is also known for high mechanical resistance and strength in compression and relatively low water absorption. Due to the high content of terpenoids it is durability to biotic and abiotic factors (Gierlinger et al. 2003). Siberian larch is highly resistant to atmospheric factors, in practice, it is considered as durable wood, which can be used in construction without any protection. Both European and Siberian larch are characterized with high strength, which gives a high percentage of use in furniture and construction (Gierlinger et al. 2003; Musil 2007).

Wood exposed to outdoor conditions is subjected to process of natural weathering, when wood degrades due to the effect of atmospheric factors and changes its surface properties both on macroscopic and microscopic level (Williams 2007). The degree of degradation is generally influenced by wood density, amount of sapwood and heartwood, annual ring's orientation and content of lignin and extractives (Williams 2005). Abiotic factors cause atmospheric degradation of wood, which negatively affects only its surface layers (Temiz et al. 2005; Evans 2008; Oberhofnerová et al. 2017) but it can be beginning of more dangerous degradation caused by biotic factors - wood-destroying fungi and insects (Feist and Hon 1984; Reinprecht 2012). The changes take place only to the depth of few millimetres and do not affect the important mechanical properties, service life or even the function of wooden element (Gobakken et al. 2011). The most significant factors influencing the rate of degradation are solar radiation and water, acting synergistically (Tolvaj\& Faix 1995; Hon \& Shiraishi 2001; Müller et al. 2003). Ultraviolet (UV) radiation provokes photochemical reactions, which cause the decomposition of lignin, extractives and partly hemicellulose (Feist \& Hon 1984; Pandey 2005; Reinprecht 2008). In the first phase, the lignin is decomposed. As a result, in indoor applications the wood turns dark, but in outdoors the decomposed parts are washed out by rainwater from the surface (Tolvaj 1995; Pandey 2005). Due to that process, the light shade of wood caused by light colour of non-degraded cellulose is formed, but it is immediately disrupted by deposition of dust particles and pollution into the porous structure of wood surface (Evans 2008). The well known greying of wood surface in exterior takes place. After leaching the products of photodegradation the layers of wood cells are further exposed and eroded (Feist 1982; Williams \& Feist 1999; Reinprecht 2008). The other factors affecting the intensity of surface degradation are temperature, acid rains and wind (Feist 1990; Williams 2005; Evans 2008; Teacà et al. 2013). The effect of wind is evident in formation of typical plastic structure of wood in exterior, which is manifested by increased roughness of surface. The uneven surface is caused mainly by the different density of early wood and late wood, which is more obvious at softwoods (Williams 1999).

Other important factors influencing weathering of wood are biotic factors and combination of wood product application and construction or design solution (Sandak et al. 2017). When applying untreated wood elements on facade, the principles of construction protection should be respected in order to significantly reduce the weathering process (EN 335; Ganne-Chédeville et al. 2012). The basic point of construction protection is keeping the optimal shape and connection of wooden facade element in order to ensure the rainwater drain. Other principles are suitable roof overhangs, which can significantly reduce the exposition of wood facade to water, or avoiding the contact of wood with ground (Ingo 2011). Geographic and climatic factors plays an important role as well in weathering. In the study of Mohebby \& Saei (2015) the influence of different cardinal points on weathering was confirmed - facades exposed to south side are more affected by intensive solar radiation and changes of relative humidity and temperature, therefore the higher protection of facade is recommended for this side. The intensity of solar radiation is lower at north side, on the other hand it is more exposed to higher humidity and slower drying out of wood, which makes suitable conditions for growth of wood-destroying fungi and moulds causing colour changes of wood (Reinprecht 2016). In the climatic conditions of Central Europe, the western side is more influenced by the predominant direction of winds and incident rainfall compared to the eastern exposure. The western side is more influenced by the predominant direction of winds and incident rainfall compared to the eastern exposure in the climatic conditions of Central Europe.

The aim of this study is to determine the influence of wood species, different exposure to cardinal points (south and north) and different type of construction on the surface changes of untreated wood facade elements. Facade models were made from European (Larix 
decidua) and, still more frequently used, Siberian larch (Larix sibirica) and they were exposed to weathering conditions in Prague (Czech Republic) in Central Europe for 24 months. The results of this study could help to understand behaviour of larch wood in exterior and its application in the form of facade cladding and to understand aesthetical changes of untreated wood during weathering.

\section{Materials and methods}

\subsection{Preparation of samples}

Based on the analysis of currently used wooden cladding, the two types of construction profiles (type A and B) and their placement were designed in software AutoCad. The accent was put on the elimination of rainwater and its faster drain from the wood surface (Fig. 1). The facade models were made from European larch (EL) and Siberian larch (SL), which were prepared in dimensions of cladding of $400 \times 145 \times 20 \mathrm{~mm}$ (length $\mathrm{x}$ width $\mathrm{x}$ thickness). The overall size of the facade models was 400 $\times 600 \mathrm{~mm}$ (width $\times$ length). The facade models were marked by the wood species, type of construction and exposure (f. e. SL-B-S, see Table 1).

Table 1. Marking of the facade models.

\begin{tabular}{lcc}
\hline Wood species & Construction type & Exposure \\
\hline Siberian larch & Type A $\times$ Type B & (South) $\mathrm{S} \times($ North) N \\
\hline SL) $\times$ European larch (EL) & & \\
\hline
\end{tabular}

Profiled cladding was sanded by sandpaper with 120 grain and then attached by fasteners to spruce wood supporting construction from the south (S) and north (N) side. These facade models were subsequently exposed in exterior stands in the inclination of $90^{\circ}$ (Fig. 2). Before exposition, the samples were showed $18 \%$ of wood moisture content.
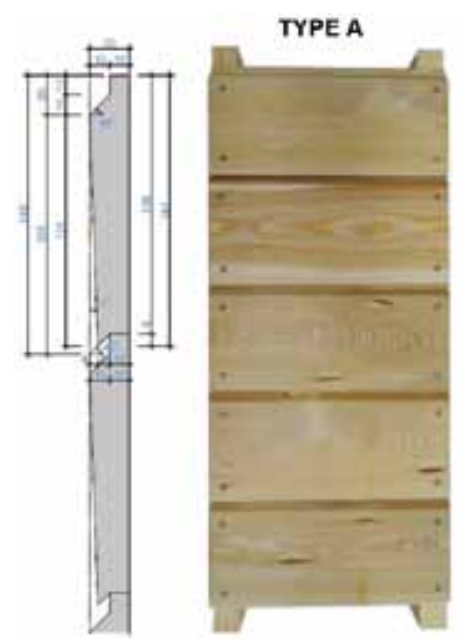

The natural weathering test took place in Czech Republic at Suchdol (50 07' 49,68 “N; $14^{\circ} 22^{\prime} 13,87^{\prime}$ ” E, $285 \mathrm{~m}$ elevation above sea level) for 24 months based on the EN 927-3 (2006). Testing stand with facade models was placed at the roof of Pavilion of Wood Sciences of Faculty of Forestry and Wood Sciences in Prague.

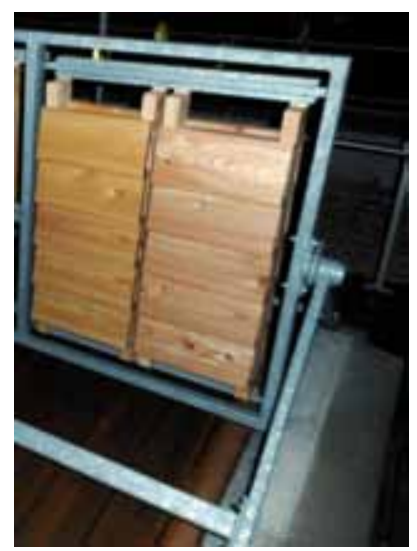

Fig. 2. The placement of facade models in the testing stands in exterior in $90^{\circ}$.

The selected surface properties were regularly examined before and after 6, 12 and 24 months of exposure: changes of gloss and colour, wettability (via measuring contact angle) and visual evaluation focused on the cracks forming and resin leaking.

\subsection{Colour measurements}

Colour parameters $L^{*} a * b *$ were determined using the spectrophotometer CM-600d (Konica Minolta, Japan) at the same marked places on the specimens. The device was set to an observation angle of $10^{\circ}, \mathrm{d} / 8$ geometry and D65 light source in $\mathrm{L}^{*} \mathrm{a}^{*} \mathrm{~b}$ * colour space (according to the Commission International de l'Eclairage-CIE 1986). Forty measurements were carried out for each

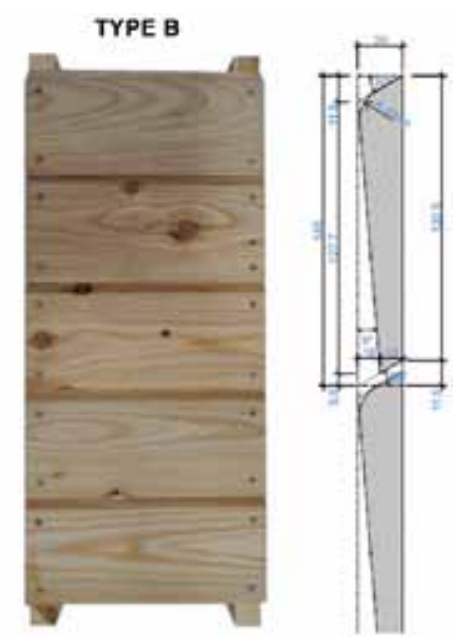

Fig. 1. Design of facade profiles - type A (left - Siberian larch) and B (right - European larch). Type A is characterized with cladding top cut in $45^{\circ}$, while type $B$ was designed with inclination $30^{\circ}$ and rounded top with radius $r=15 \mathrm{~mm}$. 
tested model - twenty for south exposure and twenty for north exposure. For the mathematical expression of difference of two colours is used the Euclidian distance - called as total colour difference $\Delta \mathrm{E} *$. The total colour difference was calculated using the following equation [Equation 1]:

$$
E^{*}=\sqrt{\left(\Delta L^{*}\right)^{2}+\left(\Delta a^{*}\right)^{2}+\left(\Delta b^{*}\right)^{2}}
$$

where:

$L *$ is the lightness from 100 (white) to 0 (black), $a *$ is the chromaticity coordinate from -60 (green) to +60 (red), $b^{*}$ is the other chromaticity coordinate from -60 (blue) to +60 (yellow) (Sehlstedt-Persson 2003).

\subsection{Gloss measurements}

Gloss measurements were performed based on EN ISO 2813 (2014) using glossmeter MG268-F2 (KSJ, Quanzhou, China). Forty measurements at a $60^{\circ}$ angle per sample (twenty for south side, twenty for north side) were performed during weathering.

\subsection{Contact angle measurements}

The sessile drop method with static contact angle measurement (without external interference) was performed using the methodology of Bastani et al. (2015). The wettability measurements were taken using a goniometer Krüss DSA 30E device (Krüss, Hamburg, Germany) on radial surfaces of wood samples before weathering and after 24 months. From each model, the samples from the south and north side after 24 months of exposure were prepared - in dimensions $70 \times 30 \times 20 \mathrm{~mm}(\mathrm{l} \times \mathrm{w} \times \mathrm{t})$. Ten measurements were taken for each sample, with distilled water drops with a dosing volume of $5 \mu \mathrm{l}$. The contact angle values were determined after $5 \mathrm{~s}$ of drop deposition to reach the equilibrium point and prevent the risk of contamination with extractives. The phenomena of spreading and absorption of drops on the wood surface was investigated via comparison between initial and weathered state of wood samples.

\subsection{Visual evaluation}

The formation of cracks and degree of surface degradation were evaluated before and after weathering using visual evaluation on the base of EN ISO 4628 (2003).

\subsection{Statistical analysis}

The statistical evaluation was performed using Statistica 12 software (Statsoft, Palo Alto, USA) and MS Excel 2013 (Microsoft, Redmond, USA) using mean values, standard deviations, whiskers plots and analysis of variance (ANOVA).

\section{Results and discussion}

The total colour difference $\Delta E^{*}$, calculated from the measured values $\left(L^{*}, a^{*}, b^{*}\right)$, was the most significant factor indicating weathering of facade models. The specific colour parameters $\left(L^{*}, a^{*}, b^{*}\right)$ represents the change of colour more accurately. During exposure of face models in exterior there was a significant change of colour, at the end of the experiment almost all the tested models were characterized with the total colour difference $\Delta \mathrm{E}^{*}>12$. This value is considered as different colour in comparison with the initial colour at the beginning of the experiment. An exception was recorded for facade models SL-B-S and EL-B-S, which were characterized with the total colour change $\Delta \mathrm{E}^{*}=9.9$ and 11.2 respectively. These values are considered as high colour change only (Sehlstedt-Persson 2003). The most significant colour changes were noted after 24 months of exposure for the facade models exposed to north side, specifically SL-A$\mathrm{N}, \mathrm{EL}-\mathrm{A}-\mathrm{N}$. Regarding south side, the most significant colour difference was recorded for the model SL-A-S with the values $\Delta E^{*}=19.3$ (Fig. 3).

When evaluating the colour parameter $\mathrm{L}$ *, a negative difference of its values was initially observed, which means that the colour of the facade models gradually changed to a darker shade. This change is mostly caused by the deposition of dust particles in exterior and by the

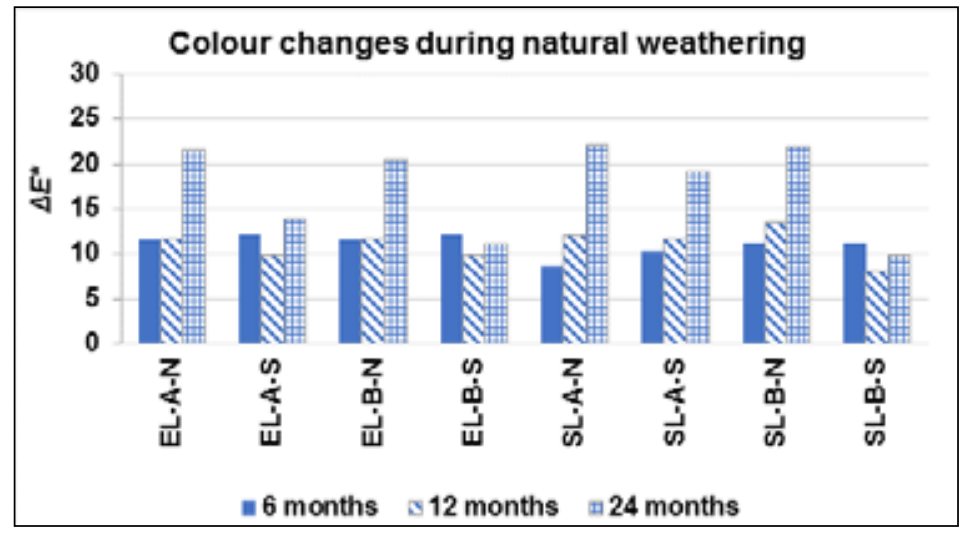

Fig. 3. Total colour changes $\Delta E^{*}$ of facade models during natural weathering. 


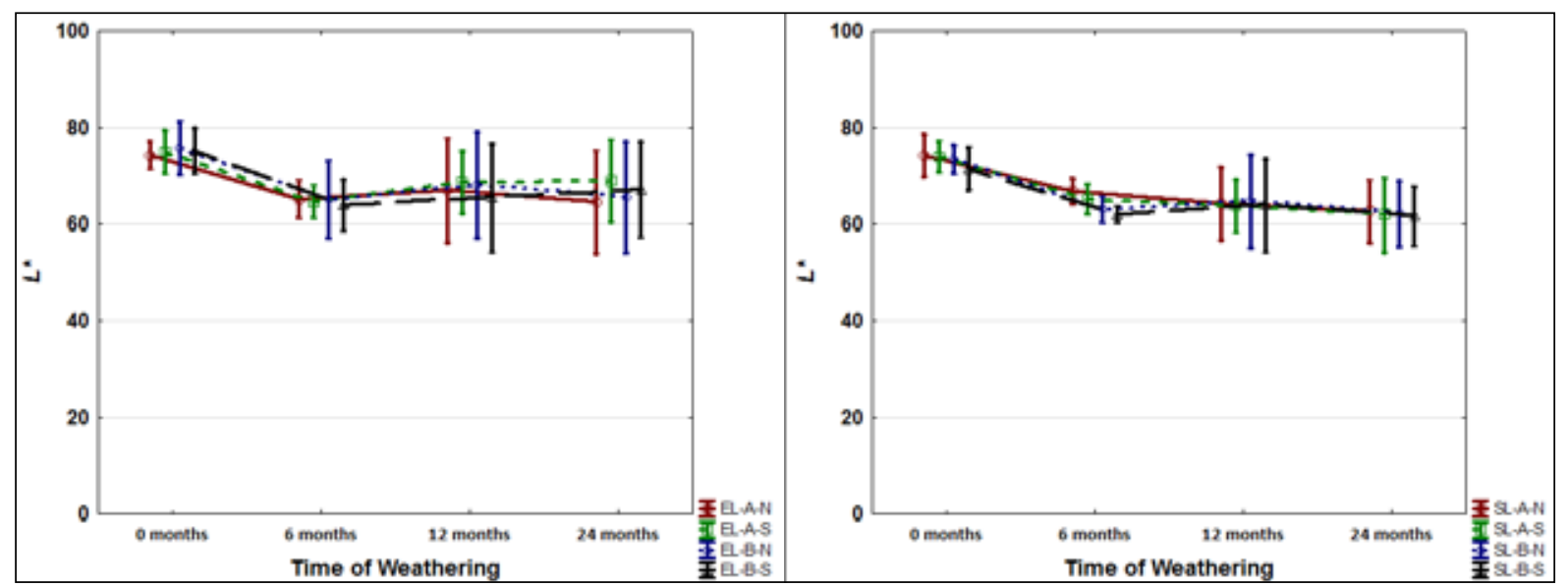

Fig. 4. 2SD whiskers plots and Mean values of $L^{*}$ changes during natural weathering of facade models from European (left) and Siberian (right) larch.

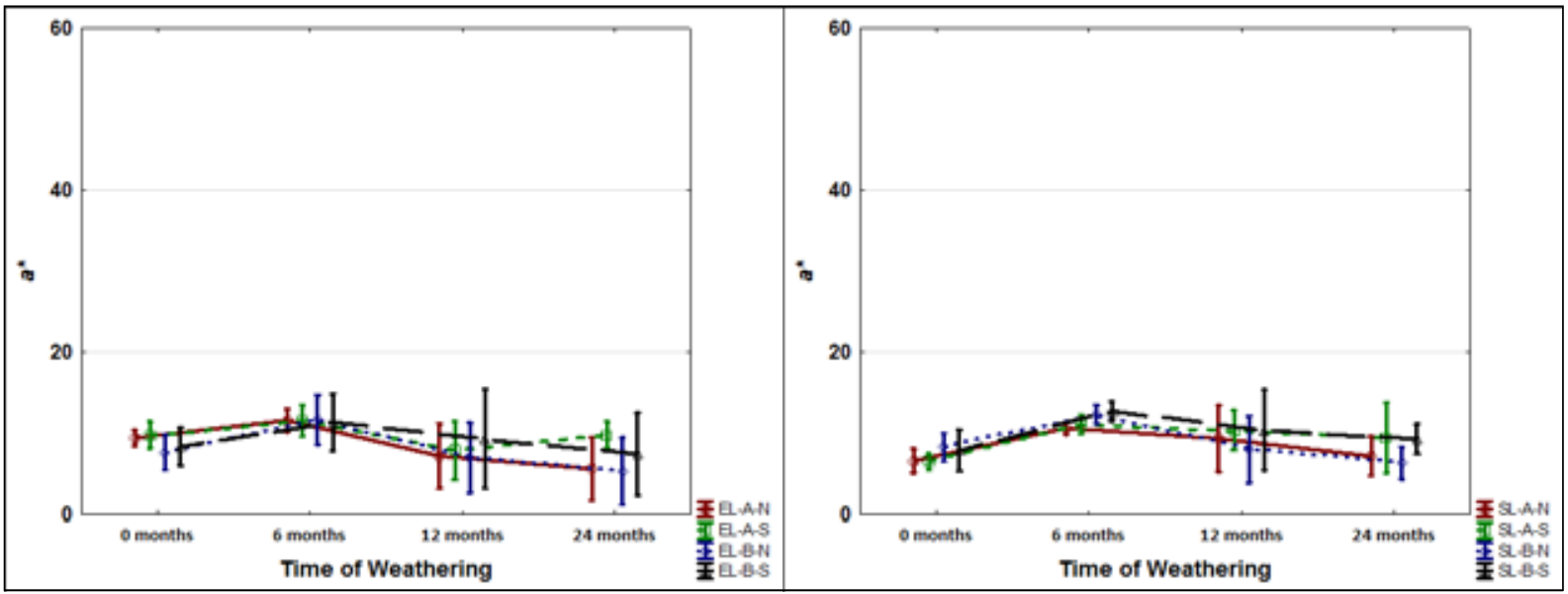

Fig. 5. 2SD whiskers plots and Mean values of $a *$ changes during natural weathering of facade models from European (left) and Siberian (right) larch.

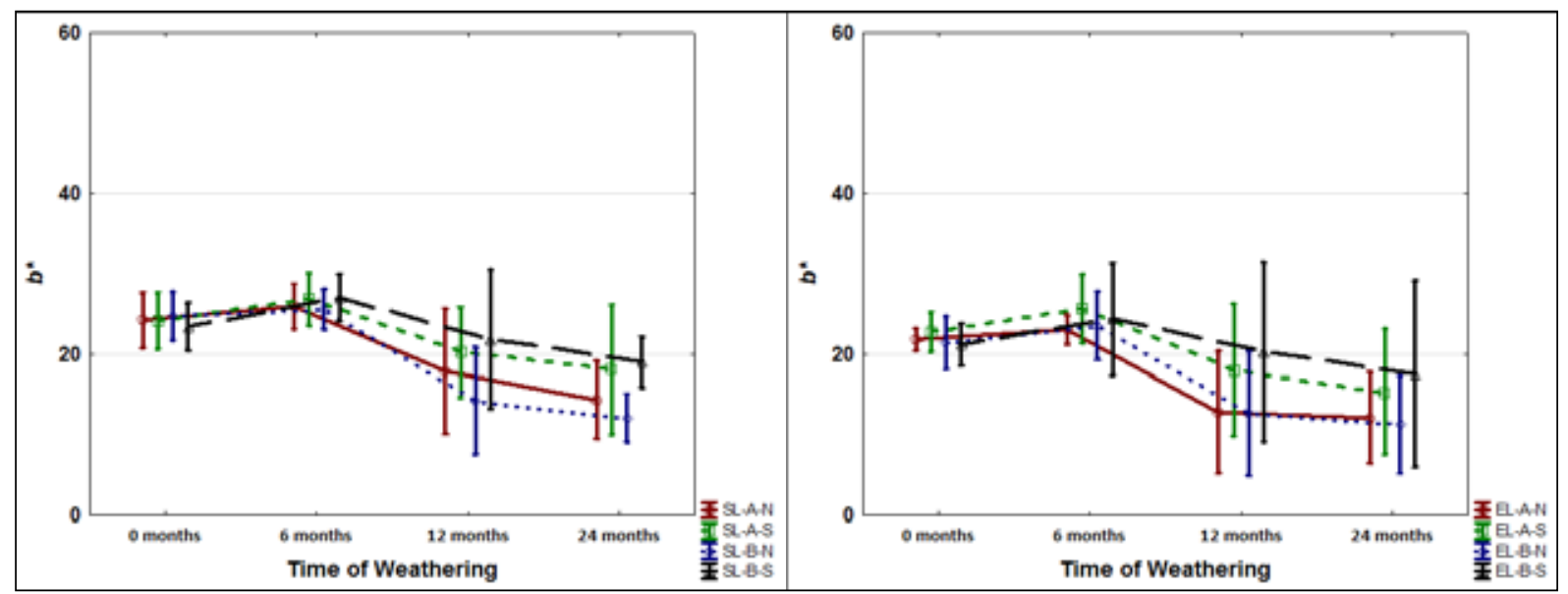

Fig. 6. 2SD whiskers plots and Mean values of $b^{*}$ changes during natural weathering of facade models from European (left) and Siberian (right) larch. 
photodegradation of extractives and lignin on wood surface (Oberhofnerová et al. 2017). The most significant difference in the values of the parameter $\Delta \mathrm{L} *$ was clearly observed at the facade models of type A, specifically in the Siberian larch (SL) on the north side (N) with $\Delta \mathrm{L}^{*}$ $=-17.9$. The second highest value was recorded for the same model on the south side with $\Delta \mathrm{L} *=-17.0$. From the point of view of this indicator of lightness, the construction type A model exposed to north side was less suitable for both wood species. For construction type $\mathrm{B}$, due to its specific inclination of the façade profiles greater than $90^{\circ}$ (see Fig. 1), there was less deposition of impurities in the porous structure and micro-cracks of the wood. The European larch on the south side best suited the construction type A of facade model. Facade models SL-B-S and EL-A-S type showed the lowest differences in lightness values.

The colour parameters $a *$ and $b$ * increased after 6 months of exposure, which is caused by the photodegradation of lignin (Müller 2003), but after 12 months this trend was completely opposite and during the exposure the values kept decreasing, which is due to gradual leaching of lignin (Pastore et al. 2004). All facade models exposed to natural weathering for 6 months showed a trend of increasing values of the parameter $a^{*}$. After 12 months of exposure, all models showed a decrease in these values. The most significant decrease was recorded for the EL-B-N and EL-A-N models. On the contrary, the least significant decrease in $\mathrm{a}^{*}$ values was measured for the SL-B-S and SL-A-S models. Overall, the north side and the European larch generally showed lower values of $a^{*}$. The highest value of the parameter $b$ * was recorded after 6 months of exposure for model SL-B-S $\left(b^{*}=27.1\right)$ and model SL-A-S $\left(b^{*}=26.9\right)$. At the end of the weathering, the most significant decrease of the parameter $b^{*}$ was measured at model EL-A-N $(b *=7.1)$ and $\mathrm{SL}-\mathrm{B}-\mathrm{N}\left(\mathrm{b}^{*}=7.9\right)$. According to the dimensional colour model, the facade models approached the yellow hue in the $6^{\text {th }}$ month and the blue hue from the $12^{\text {th }}$ month until the end of the test. The colour parameter $b$ * showed lower values of European larch compared to European larch, and lower values were also measured for the facade models on the north side than on the south side.

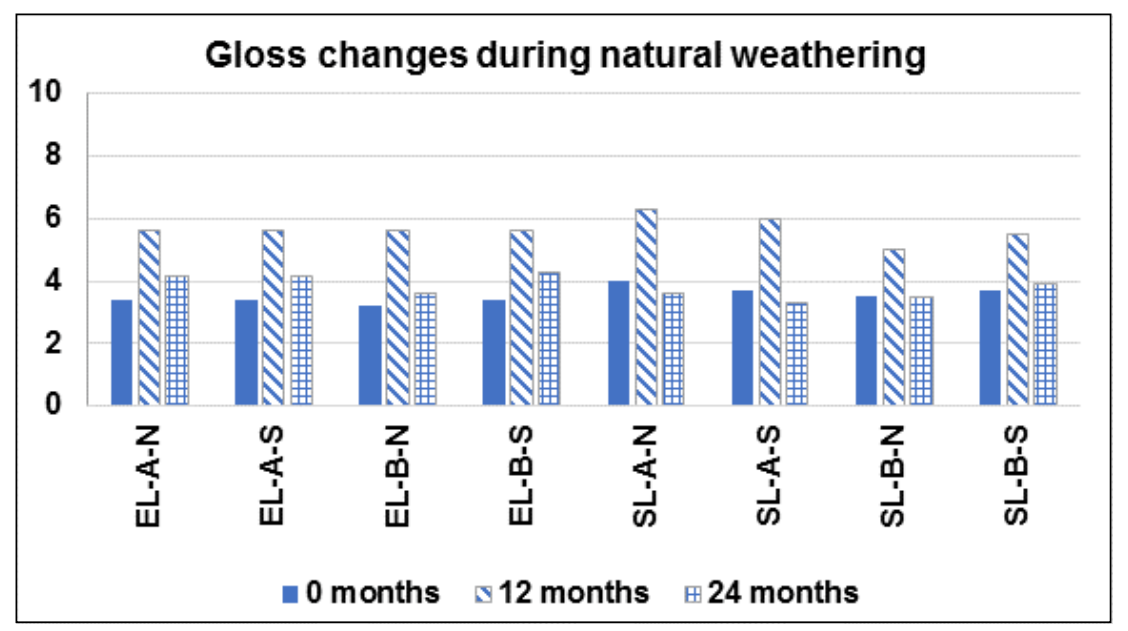

Fig. 7. Gloss changes of facade models during natural weathering.

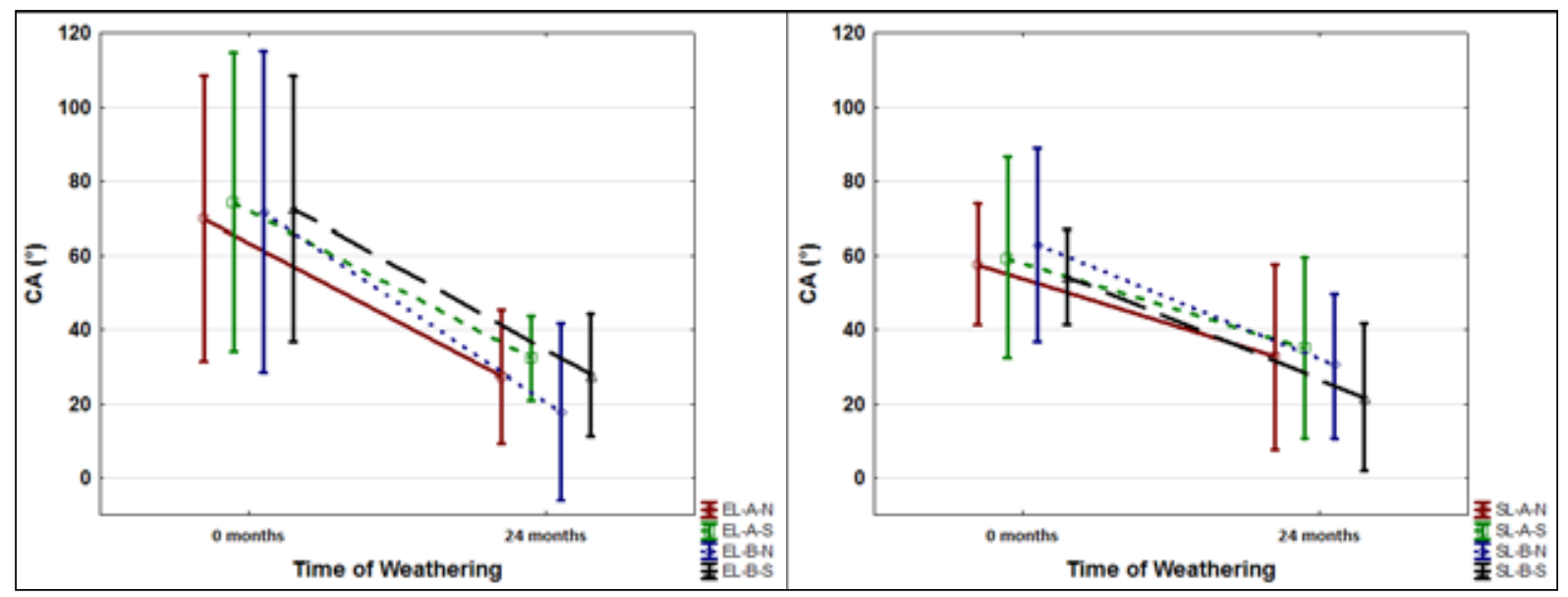

Fig. 8. Surface wetting of facade models before and after natural weathering. 
The wood of both types of tested larch had a matt surface (EN ISO 2813 2014) even before the start of the weathering (Fig. 7). During the test, there was a slight increase after 12 months of weathering and a decrease again to almost original values after 24 months of exposure. Despite some slight differences in the initial values and the course of changes, the gloss values are so low that they do not play an important role in the visual perception of the facade cladding for the external observer.

The contact angle of surface wettability with water showed considerable variability due to the inhomogeneous structure of larch wood even before weathering (Fig. 8). This inhomogeneity was slightly lower at SL with higher density of annual rings, where the deposited drop with a volume of $5 \mu \mathrm{l}$ always partially affected the zone of early wood and late wood. For EL with wider annual rings, the variability was higher. The places with a higher resin content were other reason for the variability of results (see photos in Fig. 1). After weathering, significant decrease in contact angle values $\left(\mathrm{CA}^{\circ}\right)$ and a decrease in variability of $E L$ were observed. This action was due to the gradual photodegradation and leaching of hydrophobic lignin from wood surfaces (Pastore et al. 2004). In general, lower $\mathrm{CA}^{\circ}$ values were measured for facade model B (lowest for EL-B-N), but the differences were not statistically significant (Fig. 8). The decrease is not as significant as in study of Oberhofnerová \& Pánek (2016), which is, however, due to the $90^{\circ}$ inclination of the wood in this experiment, where there is no such rapid weathering compared to exposure in the inclination of $45^{\circ}$ according to EN 927-3 (2006).

Visual evaluation of facade models confirmed more significant formation of cracks at SL-A-S in comparison with other models. These visual changes were observed after 12 months of weathering (Fig. 9). In this Figure, it is also possible to see typical greying of wood in exterior.

In some cases, resin leaking was observed, especially in the first 12 months of exposure (Fig. 10). This characteristic was the most pronounced at SL-B-S model.

The colour changes were observed even by naked eye, which confirms the values of total colour difference measured by spectrophotometer (Fig. 3).

\section{Conclusion}

Two construction types of facade models were made from European Larch (Larix decidua Mill.) and Siberian Larch (Larix sibirica). These models were subjected to natural weathering for 24 months on the south and north exposure. The colour changes at all models were significant, the lowest changes were observed for SLB-S model. But in general, the most significant overall colour changes were paradoxically shown by the facade models made of Siberian larch. In terms of the indicator of total colour difference, the European larch reached in more cases better results than Siberian.

In terms of type of exposure, the north side showed higher colour changes compared to the south side.
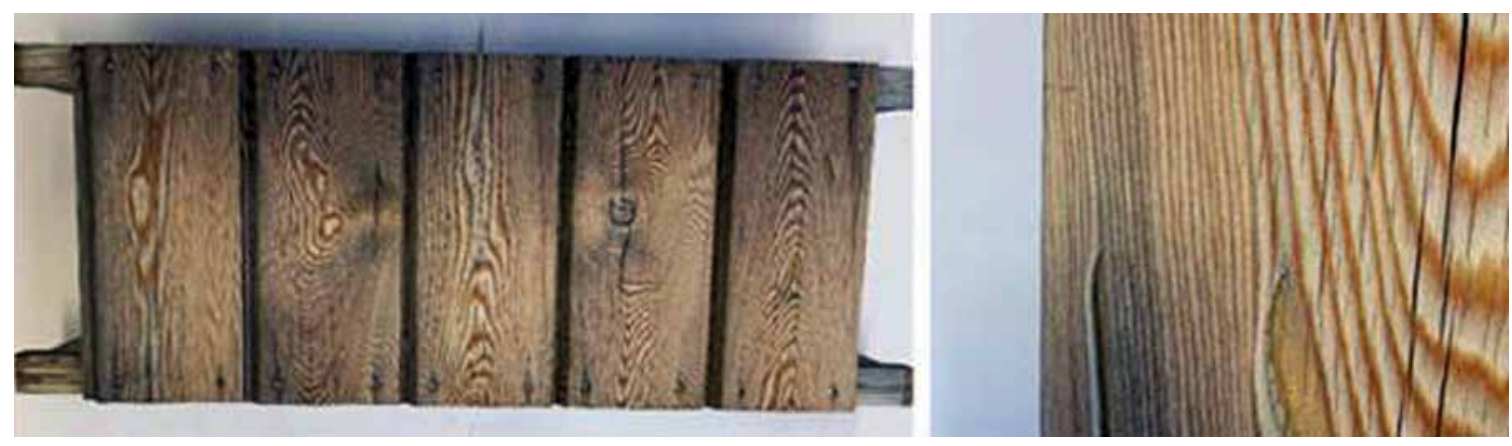

Fig. 9. The formation of cracks - visual appearance of Siberian larch after 12 months of exposure to south side, construction type A.
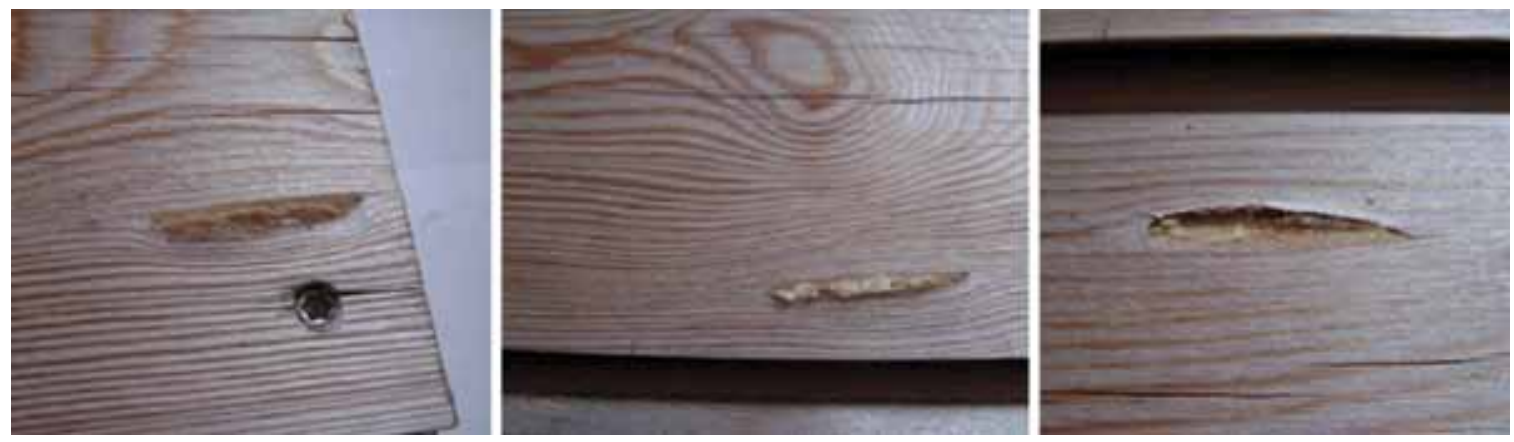

Fig. 10. The resin leak after 12 months of weathering at Siberian larch exposed to south side, construction type B. 
Another evaluation parameter was the gloss, where, however, due to its low initial values and small changes, the visual characteristics of the facade models were not significantly affected. A more significant decrease in the contact angle of wettability was observed for European larch and for facade model B, but the differences after weathering were not statistically significantly different due to the large variability of the measured values. There was a higher formation of cracks on Siberian larch wood in comparison with European larch. Cracks were observed on both types of exposure $(\mathrm{N} \times \mathrm{S})$ and construction models $(\mathrm{A} \times \mathrm{B})$ but the most at the facade model A on the south side. The occurrence of resin leaking during outdoor exposure was also observed, especially in the first 12 months of exposure.

Finally, the main result of this work is that changes of larch façade appearance during exterior exposure depend not only on kind of larch wood, north or south exposure, but important factor is also design of profiles in construction.

\section{Acknowledgements}

The authors are very grateful for the financial support of the project Expanding and supporting the transfer of technologies and knowledge at CULS by activities of "proof-of-concept", reg. no. CZ.07.1.02/0.0/0.0/16_023/0000111-Activity KZ04Development of facade wood cladding with increased durability and colour stability.

\section{References}

Bastani, A., Adamopoulos, S., Militz, H., 2015: Water uptake and wetting behaviour of furfurylated, $\mathrm{N}$ methylol melamine modified and heat-treated wood. European Journal of Wood and Wood Products, 73:627-634.

Bribiàn, I. Z., Capilla, A. V., Usón, A. A., 2011: Life cycle assessment of building materials: Comparative analysis of energy and environmental impacts and evaluation of the eco-efficiency improvement potential. Building and Environment, 46:1133-1140.

Brischke, C., Rapp, A. O., 2008: Dose-response relationships between wood moisture content, wood temperature and fungal decay determined for 23 European field test sites. Wood Science and Technology, 42:507-518.

Connell, M., 2004: Issues Facing Preservative Suppliers in Changing Market for Treated Wood (COST E22, Brussels), 8 p.

Evans, P. D., 2008: Weathering and photo-degradation of wood. Development of Wood Preservative Systems, ACS Symposium Series, American Chemical Society, p. 69-117.

Feist, W. C., 1982: Weathering of wood in structural uses. In: Structural use of wood in adverse environments. Van nostrand reinhold, p. 156-178.
Feist, W. C., 1990: Outdoor wood weathering and protection. In: Archaeological wood: properties, chemistry, and preservation. Advances in Chemistry Series 225. Proceedings of 196th meeting of the American Chemical Society, p. 25-28.

Feist, W. C., Hon, D. N.-S., 1984: Chemistry of weathering and protection. In: R. M. Rowell (ed.): The Chemistry of Solid Wood (Washington, DC: American Chemical Society), p. 401-451.

Ganne-Chédeville, Ch., Jääskeläinen, A. S., Froidevaux, J., Hughes, M., Navi, P., 2012: Natural and artificial ageing of spruce wood as observed by FTIR-ATR and UVRR spectroscopy. Holzforschung, Berlin, 66:163-170.

Gielen, D., 1997: Building Materials and CO2-Western European Emissions Reduction Strategies. MATTER Project Report (Petten: Netherlands Energy Research Foundation (ECN)).

Gierlinger, N., Jacques, D., Schwanninger, M., Wimmer, R., Pâques, L. E., 2003: Heartwood extractives and lignin content of different larch species (Larix sp.) and relationships to brown-rot decay-resistance. Trees, 18:230-236.

Gobakken, L. R., Høibø, O.A., 2011: Aesthetic servicelife of coated and uncoated wooden cladding-influencing factors and modelling. In: The 42nd Annual Meeting of IRG. International Research Group on Wood Protection IRG/WP, 11-20470:20.

Goverse, T. et al., 2001: Wood innovation in the residential construction sector; opportunities and constraints. Resources, Conservation and Recycling, 34:53-74.

Gupta, B. S., Jelle, B. P., Hovde, P. J., Rüther, P., 2011: Studies of wooden cladding materials degradation by spectroscopy. Proceedings of the Institution of Civil Engineers - Construction Materials, 164:329-340.

Hirche, M., 2014: Wood Weathering as Design Option. Dissertation, Norwegian University of Science and Technology, $272 \mathrm{p}$.

Hon, D. N. S.; Shiraishi, N., 2001c: Wood and cellulosic chemistry. 2nd ed., rev. And expanded. New York: Marcel Dekker, 928 p.

Hrapková, L., Rychtář, J., Veselý, V., 2012: Fasádní obklady dřevěné a z materiálů na bázi dřeva. Stavební partner, 1:1-12.

Ingo, G., 2011: Dřevěné fasády: materiály, návrhy, realizace. Praha, Grada, 136 p.

Kržišnik, D., Lesar, B., Thaler, N., Humar, M., 2018: Micro and materiál climate monitoring in wooden buildings in sub-Alpine environments. Available online: https://www.sciencedirect.com/science/ article/pii/S0950061818301417 (accessed on 20 April 2020).

Lesar, B., Humar, M., Kržišnik, D., Thaler, N., Žlahtič, M., 2016: Performance of façade elements made of five different thermally modified wood species on model house in Ljubljana. In: Proceedings of the World Conference on Timber Engineering, Vienna, 22-25 August 2016. 
Mohebby, B., Saei, A. M., 2015: Effects of geographical directions and climatological parameters on natural weathering of fir wood. Construction and Building Materials, 94:684-690.

Müller, U., Rätzsch, M., Schwanninger, M., Steiner, M., Zöbl, H., 2003: Yellowing and IR-changes of spruce wood as result of UV-irradiation. Journal of Photochemistry and Photobiology B: Biology, 69:97-105.

Musil, I., Hamerník, J., 2007: Jehličnaté dřeviny - Lesnická dendrologie I. Praha, Academia, 352 p.

Oberhofnerová, E., Pánek, M., 2016: Surface wetting of selected wood species by water during initial stages of weathering. Wood Research, 61:545-552.

Oberhofnerová, E., Pánek, M., García-Cimarras, A., 2017: The effect of natural weathering on untreated wood surface. Maderas: Ciencia y Tecnologia, 19:173-184.

Pandey, K. K., 2005: A note on the influence of extractives on the photo-discoloration and photo-degradation of wood. Polymer Degradation and Stability, 87:375379.

Pastore, T. C. M., Santos, K. O., Rubim, J. C., 2004: A spectrocolorimetric study on the effect of ultraviolet irradiation of four tropical hardwoods. Bioresource Technology, 93:37-42.

Požgaj,A., Chovanec, D., Kurjatko, S., Babiak, M., 1993: Štruktúra a vlastnosti dreva. Bratislava, Príroda, $485 \mathrm{p}$.

Reinprecht, L., 2012: Ochrana dreva. Zvolen, Technical University in Zvolen, 453 p.

Reinprecht, L., 2016: Wood Deterioration, Protection and Maintenance; John Wiley \& Sons, Chichester, UK, 376 p.

Reinprecht, L., Vidholdová, Z., 2008: Mould resistance, water resistance and mechanical properties of OHT-thermowoods. Sustainability through New Technologies for Enhanced Wood Durability: Socioeconomic perspectives of treated wood for the common European market, p. 159-165.

Sandak, A., Sandak, J., 2017: Prediction of service lifedoes aesthetic matter? In: Proceedings IRG Annual Meeting, Ghent, Belgium, 4-8 June 2017. Available online: https://www.researchgate.net/publication/318212393 (accessed on 23 April 2020).

Sehlstedt-Persson, M., 2003: Color responses to heattreatment of extractives and sap from pine and spruce. In: Proceedings of the 8th IUFRO InternationalWood Drying Conference: Improvement and Innovation in Wood Drying: A Major Issue for a Renewable Material, Brasov, Romania, 24-29 August 2003; Faculty of Wood Industry, Transilvania University of Brasov, p. 459-464.

Sohngen, B., Mendelsohn, R., Sedjo, R., 1999: Forest management, conservation, and global timber markets. American Journal of Agricultural Economics, 81:1-13.
Teacà, C. A., Rosu, D., Bodirlau, R., Rosu, L., 2013: Structural changes in wood under artificial UV light irradiation determined by FTIR spectroscopy and color measurements-A brief review. BioResources, 8:1478-1507.

Temiz, A., Yildiz, U.C., Aydin, I., Eikenes, M., Alfredsen, G., 2005: Surface roughness and color characteristics of wood treated with preservatives after accelerated weathering test. Applied Surface Science, 250:35-42.

Tolvaj, L., Faix, O., 1995: Artificial ageing of wood monitored by DRIFT spectroscopy and CIE $\mathrm{L}^{*} \mathrm{a}{ }^{*} \mathrm{~b}$ * color measurements. 1. Effect of UV light. 113 Holzforschung-International Journal of the Biology, Chemistry, Physics and Technology of Wood, 49:397-404.

Wagenführ, R., 2003: Dřevo - obrazový lexikon. No: 1, Př́bram, Tiskárny Pbtisk Příbram, 348 p.

Williams, R. S., Feist, W. C., 1999: Water repellents and water-repellent preservatives for wood. Forest Products Laboratory, $12 \mathrm{p}$.

Williams, R. S., Knaebe, M. T., Feist, W. C., 2007: Erosion rates of wood during natural weathering. Part II, Earlywood and latewood erosion rates. Wood and Fiber Science, 33:43-49.

Williams, R. S., 2005: Handbook of wood chemistry and wood composites. In: R. M. Rowell (ed.): Boca Raton, Fla: CRC, 703 p.

\section{Other sources}

CIE, 1986: Colorimetry. 2nd Edition, CIE Pub. No. 15.2, Commission Internationale de l'Eclairage, Vienna, $74 \mathrm{p}$.

EN 335 (2013): Durability of wood and wood-based products - Use classes: definitions, application to solid wood and wood-based products. European Committee for Standardisation (CEN), Brussels, Belgium.

EN 350 (2016). Durability of wood and wood-based products - Testing and classification of the durability to biological agents of wood and wood-based materials, European Committee for Standardization, Brussels, Belgium.

EN 927-3 (2006). Paints and varnishes. Coating materials and coating system for exterior wood, Part 3: Natural weathering test, European Committee for Standardization, Brussels, Belgium.

EN ISO 2813 (2014). Paints and Varnishes - Determination of Gloss Value at 20 Degrees, 60 Degrees and 85 Degrees, International Organization for Standardization: Geneva, Switzerland.

EN ISO 4628 (2003). Paints and varnishes. Evaluation of degradation of coatings. Designation of quantity and size of defects, and of intensity of uniform changes in appearance, European Committee for Standardization, Brussels, Belgium. 